\title{
Macroalgae Derived Fungi Have High Abilities to Degrade Algal Polymers
}

\author{
Aleksandrina Patyshakuliyeva ${ }^{1}$, Daniel L. Falkoski ${ }^{1}$, Ad Wiebenga ${ }^{1}$, Klaas Timmermans ${ }^{2}$ and \\ Ronald P. de Vries $1, * \mathbb{D}$ \\ 1 Fungal Physiology, Westerdijk Fungal Biodiversity Institute \& Fungal Molecular Physiology, Utrecht \\ University, Uppsalalaan 8, 3584 CT Utrecht, The Netherlands; a.patyshakuliyeva@nioo.knaw.nl (A.P.); \\ dalf@novozymes.com (D.L.F.); a.wiebenga@westerdijkinstitute.nl (A.W.) \\ 2 NIOZ Royal Netherlands Institute for Sea Research, Landsdiep 4, 1797 SZ 't Horntje, The Netherlands; \\ klaas.timmermans@nioz.nl \\ * Correspondence: r.devries@westerdijkinstitute.nl; Tel.: +31-(0)30-212-2600
}

Received: 22 November 2019; Accepted: 26 December 2019; Published: 26 December 2019

\begin{abstract}
Marine fungi associated with macroalgae are an ecologically important group that have a strong potential for industrial applications. In this study, twenty-two marine fungi isolated from the brown seaweed Fucus sp. were examined for their abilities to produce algal and plant biomass degrading enzymes. Growth of these isolates on brown and green algal biomass revealed a good growth, but no preference for any specific algae. Based on the analysis of enzymatic activities, macroalgae derived fungi were able to produce algae specific and (hemi-)cellulose degrading enzymes both on algal and plant biomass. However, the production of algae specific activities was lower than the production of cellulases and xylanases. These data revealed the presence of different enzymatic approaches for the degradation of algal biomass by macroalgae derived fungi. In addition, the results of the present study indicate our poor understanding of the enzymes involved in algal biomass degradation and the mechanisms of algal carbon source utilization by marine derived fungi.
\end{abstract}

Keywords: seaweed biomass; enzymes; algal polysaccharides; marine fungi

\section{Introduction}

Macroalgae represent a promising renewable resource for the production of sustainable bioenergy and biomaterials and as ingredients in the development of new food and feed products [1]. They are fast growing and rich in proteins, carbohydrates, bioactive compounds, vitamins, and macroand microelements. Interest in macroalgae-based research has recently increased due to the rise in the world population and expected greater demand for food, feed, and fuel. One of the main challenges to efficiently extract valuable compounds from macroalgal biomass is structurally rigid and complex cell wall polysaccharides of seaweeds [2-4]. Cell wall polysaccharides of seaweeds are species dependent and significantly different from terrestrial plants. For instance, they include ulvan, a sulfated glucuronoxylorhamnan, in green macroalgae Ulva lactuca [5]; alginate and sulfated polysaccharides, such as fucoidan, in brown macroalgae, such as Saccharina latissima, Laminaria digitata, and Fucus vesiculosus $[4,6,7]$. Macromolecular composition of seaweed is also varied with seasons and nutrient availability $[8,9]$. For instance, it has been shown that the highest carbohydrate content was in spring [10] and summer [11] in green seaweed, $U$. lactuca, with increased rhamnosyl and glucuronoyl residues in April [10]. In contrast, in brown seaweed, S. latissima, it was demonstrated that alginate content was the highest during summer and the lowest during autumn [12,13]. In addition to algae-specific polysaccharides, seaweeds contain cellulose which is also a structural component of plants. However, cellulose in most plants is complexed with lignin, while this is not the case in 
macroalgae, enabling easier degradation or extraction. The presence of lignin in plant cell wall and its association with cellulose hinders the accessibility of plant cell wall polysaccharides to enzymatic treatment such as decreases in the length of cellulose that can be processed or limits the surface area for enzymes to bind [14-16].

Current methods of breaking up the macroalgal cell wall to extract valuable compounds are not optimal and have disadvantages of high energy consumption in case of mechanical methods, harsh conditions and toxicity during chemical extraction, and generation of side products and waste if high temperatures are used [17-19]. In contrast, it has been demonstrated that enzyme-assisted extraction holds big potential for development of targeted and sustainable processing of seaweeds [2,3,20,21]. Therefore, identification of enzymes involved in the specific degradation of algal cell walls is very important.

Fungi represent a large and diverse group of microorganisms in microbiological communities in the marine environment and have an important role in nutrient cycling [22]. They are divided into two major groups; obligate marine fungi and facultative marine fungi [23]. Obligate marine fungi are adapted to reproduce in the aquatic environment, while facultative marine fungi can grow in aquatic as well as terrestrial environments [23]. Marine fungi are called marine-derived fungi when their facultative or obligate state is not certain [23]. Marine fungal species occur as saprobes, parasites, or symbionts and colonize a wide range of substrates, such as sponges, corals, mangroves, seagrasses and algae [24,25]. Marine fungi associated with algae are largely unexplored, despite their ecological role and potential industrial applications. For example, it has been shown that fungi associated with algae produce many bioactive secondary metabolites [26-28]. Algae derived fungi can be associated with a variety of algae, including brown (e.g., Agarum clathratum, Fucus sp., Laminaria sp., Sargassum sp.), green (e.g., Ulva sp., Enteromorpha sp., Flabellia sp.), or red (e.g. Chondrus sp., Dilsea sp., Ceramium sp.) algae [29-33].

The most commonly described fungi associated with algae belong to the Ascomycota and are represented by a wide diversity of genera such as Acremonium, Alternaria, Aspergillus, Cladosporium, Phoma, Penicillium, Trichoderma, Emericellopsis, Retrosium, Spathulospora, Pontogenia, and Sigmoidea [30-32,34-36]. Many of these genera also contain terrestrial species that are known to produce plant biomass degrading enzymes that convert lignocellulosic material into different high value products including biofuels and biochemicals [37]. For instance, enzymes from terrestrial species of Trichoderma [38] and Aspergillus [39] have been produced commercially for industrial applications. However, production of plant based biofuels and other high value products have some disadvantages, which include competition with agriculture for cropland, only two to four times a year harvesting, and optimal growth conditions that involve energy-consuming techniques for further processing [40]. In contrast, seaweeds do not need freshwater and land for their cultivation and can grow in salt water or waste water [40]. They have high photosynthetic efficiency and are fast-growing organisms with biomass yields that are significantly higher than those for terrestrial plants [40,41]. Moreover, macroalgae have low lignin content and consequently, are suitable for the enzymatic downstream processing with milder, less energy consuming and less costly pretreatments compared to plant biomass [42]. Since almost one-third of all known marine fungal species is associated with algae [43], their enzymes are likely well adapted to degrade the polymers in macroalgal cell walls.

In the present study, we isolated and identified marine fungi from the brown seaweed Fucus sp. to investigate their abilities to degrade algal polymers. Isolated seaweed derived fungi were analyzed for the production of algal and plant biomass degrading enzymes to expand the existing knowledge of aquatic carbon utilization by marine fungi and the potential of marine fungal enzymes in various industrial applications. 


\section{Materials and Methods}

\subsection{Materials and Culture Conditions}

Fucus sp. was used to isolate fungi by sampling them with a small brush and then plating this onto malt extract agar (MEA) plates with seawater, followed by incubation at $25^{\circ} \mathrm{C}$ for $2-5$ days. For sporulating fungi, axenic cultures were derived by streaking a small amount of conidia, collected with the tip of an inoculation needle, on MEA plates, which allowed conidia to separate. After $24 \mathrm{~h}$ to $48 \mathrm{~h}$ of incubation, plates were observed under a dissection microscope at $50 \times$ magnification and single germinating conidia were collected and transferred to MEA and incubated at $25^{\circ} \mathrm{C}$ for one week to obtain pure cultures. For non-sporulating fungi, pure cultures were obtained by transferring actively growing hyphal tips onto fresh MEA plate.

The brown seaweed, F. vesiculosus, was collected in May 2013 from the beach at Scheveningen, the Netherlands. After collection, the samples were washed extensively with water to remove sand, salt and other contaminants. The material was then dried at $60{ }^{\circ} \mathrm{C}$ and ground in a Retch mill to particles with a size $\leq 20 \mu \mathrm{m}$. The same method was used for other seaweeds (Fucus sp., L. digitata, Saccharina sp., Sargassum sp., U. lactuca) that were collected at NIOZ (Texel, The Netherlands) from either incubation tanks with seawater or directly from the sea. The ground biomass was then used as substrate for the growth profile of the fungi.

\subsection{Growth and Utilization of Algal Carbon Sources}

The seaweed isolates, the terrestrial fungus Aspergillus nidulans FGSC A4 [44], and Aspergillus sydowii CBS 593.65, a pathogen of corrals, that has both a terrestrial and a marine life style [45], were grown on MEA to produce spores, which were harvested with ACES buffer [10 $\mathrm{mM}$ N-(2-acetamido)-2-aminoethanesulfonic acid] (Sigma-Aldrich, Zwijndrecht, The Netherlands), 0.02\% Tween 80, pH 6.1-7.5]. The two Aspergilli were chosen as reference strains as they enable comparison to a terrestrial species (A. nidulans) and a species that lives both in terrestrial and marine biotopes (A. sydowii). Growth profile of these isolates was performed in duplicate using aspergillus minimal medium (AMM) [46] with 1\% (w/v) glucose or 1\% (w/v) powdered brown seaweed, F. vesiculosus. Agar plates were inoculated in the center with $10^{6}$ spores $\mathrm{mL}^{-1}$ or with an agar plug and incubated at $25^{\circ} \mathrm{C}$ for 3 days.

Nine selected isolates, and two reference strains, A. nidulans and $A$. sydowii, were grown in duplicate on AMM with $1 \%(w / v)$ different macroalgae species, or $1 \%(w / v)$ wheat bran, or $1 \%(w / v)$ glucose, or $1 \%(w / v)$ agar at $25^{\circ} \mathrm{C}$ for $3-4$ days.

For liquid cultures, $50 \mathrm{~mL}$ of AMM containing different carbon sources in a $250 \mathrm{~mL}$ flask was inoculated with $10^{6}$ spores $\mathrm{mL}^{-1}$ and incubated at $25^{\circ} \mathrm{C}, 200 \mathrm{rpm}$. Tested carbon sources were $1 \%(w / v)$ alfalfa meal, $1 \%(w / v)$ corn powder, $1 \%$ U. lactuca, and $1 \%$ L. digitata.

\subsection{DNA Extraction, PCR Amplification and Sequencing}

For molecular analysis, fungi were grown on MEA covered with a polycarbonate membrane containing $0.1 \mu \mathrm{m}$ pores (GVS Life Sciences, Sanford, ME, USA) at $25{ }^{\circ} \mathrm{C}$ for 4 days. Fresh mycelium removed from the polycarbonate membrane with a sterile loop and DNA was extracted using the Wizard ${ }^{\circledR}$ Genomic DNA Purification Kit (Promega, Leiden, The Netherlands) according to the manufacturer's instructions. Parts of the following loci were amplified and sequenced for all isolated fungi: internal transcribed spacer (ITS) regions and intervening 5.8S nuclear ribosomal RNA (nrRNA) gene; large subunit (LSU), partial nrRNA gene large subunit (28S). The genera Cladosporium, Penicillium, Clonostachys, Rhizopus, Epicoccum, Trichoderma, Aspergillus, Alternaria, Engyodontium, Exophiala, Symmetrospora, Cryptococcus, and Leucosporidium were identified based on the sequencing results of the ITS and LSU regions. The predominant genera were Cladosporium (five isolates) and Penicillium (four isolates). Four yeast isolates were identified and represented the genera Exophiala, Symmetrospora, Cryptococcus, and Leucosporidium. 
For the selected nine isolates, several additional loci were amplified and sequenced: ACT, partial actin gene; CMD, partial calmodulin gene; TEF, parts of the elongation factor $1 \alpha$; BTUB, partial $\beta$-tubulin fragments.

The primers V9G [47] and LR5 [48]/RLR3R [49] were used to amplify the ITS + LSU region and primers Bt2a and Bt2b [50] were used to amplify BTUB by using the following PCR program: initial denaturation at $94{ }^{\circ} \mathrm{C}$ for $5 \mathrm{~min}$, followed by 35 cycles of $94{ }^{\circ} \mathrm{C}$ for $30 \mathrm{~s}, 52{ }^{\circ} \mathrm{C}$ for $30 \mathrm{~s}, 72{ }^{\circ} \mathrm{C}$ for $2 \mathrm{~min}$, and finally an additional $7 \mathrm{~min}$ at $72^{\circ} \mathrm{C}$. The primers ACT-512F and ACT-783R were used for ACT [51], primers CMD5 and CMD6 for CMD [52] and primers EF1c and EF6 for TEF [53]. The following PCR program was used: the initial denaturation step was done at $94{ }^{\circ} \mathrm{C}$ for $5 \mathrm{~min}$, followed by 40 cycles of denaturation at $94{ }^{\circ} \mathrm{C}$ for $30 \mathrm{~s}$, annealing at $52{ }^{\circ} \mathrm{C}$ for $30 \mathrm{~s}$, and elongation at $72{ }^{\circ} \mathrm{C}$ for $30 \mathrm{~s}$ [54].

All PCR products were purified using Wizard ${ }^{\circledR}$ SV Gel and PCR Clean-Up System (Promega, USA). Purified PCR amplicons were sequenced by the Macrogen Europe, the Netherlands, using the same primer pairs used for PCR amplification, with additional sequence reactions set up for ITS with ITS4 and ITS5 primers [55] and LSU with primers NL1 and LR5 [48]/RLR3R [49].

Contigs were assembled by using the forward and reverse sequences with the program SeqMan from the LaserGene v. 9 package (DNAstar, Madison, WI, USA). Each sequence was subjected to BLAST search (https://blast.ncbi.nlm.nih.gov/Blast.cgi) and to Pairwise sequence alignment (http: //www.westerdijkinstitute.nl/Collections/) to verify its identity. All the sequences generated in this study were deposited in GenBank. The nine selected fungal isolates were deposited in the culture collection (CBS) of the Westerdijk Fungal Biodiversity Institute, Utrecht, The Netherlands.

\subsection{Enzyme Assays}

Culture samples $(3 \mathrm{~mL})$ from shaken cultures were taken at $60 \mathrm{~h}$ and $120 \mathrm{~h}$, and centrifuged for $10 \mathrm{~min}$, at $\sim 10,000 \times g, 4{ }^{\circ} \mathrm{C}$ to separate the solid fraction from the supernatant. The supernatants from duplicate flask cultures were used for enzymatic assays. Endoglucanase and xylanase activities were determined against carboxymethyl cellulose (CMC) and beechwood xylan (Sigma-Aldrich, Zwijndrecht, Netherlands), respectively. The assays contained a total volume of $100 \mu \mathrm{L}$ using $10-50 \mu \mathrm{L}$ of culture filtrates and $50 \mu \mathrm{L}$ of $1 \%$ substrate in $100 \mathrm{mM}$ sodium acetate buffer $\mathrm{pH}$ 5.0. The samples were incubated in microtiter plates for $30 \mathrm{~min}$ at $50{ }^{\circ} \mathrm{C}$. Subsequently, $100 \mu \mathrm{L}$ of supernatant was mixed with $100 \mu \mathrm{L} \mathrm{3,5-dinitrosalicylic} \mathrm{acid} \mathrm{(DNS)} \mathrm{solution.} \mathrm{After} \mathrm{an} \mathrm{incubation} \mathrm{of} 30 \mathrm{~min}$ at $95{ }^{\circ} \mathrm{C}$, absorbance was measured at $540 \mathrm{~nm}$ in a microtiter plate reader (FLUOstar OPTIMA, BMG LabTech, Ortenberg, Germany).

Alginase, carrageenase, fucoidanase and laminarinase activities were assayed using sodium alginate, carrageenan, fucoidan from F. vesiculosus and laminarin from L. digitata, respectively (Sigma-Aldrich, Germany). The assay contained a total volume of $100 \mu \mathrm{L}$ using $10-50 \mu \mathrm{L}$ of culture filtrates and $50 \mu \mathrm{L}$ of $0.5 \%$ substrate in $100 \mathrm{mM}$ sodium acetate buffer $\mathrm{pH}$ 5.0. The samples were incubated in microtiter plates for $60 \mathrm{~min}$ at $50{ }^{\circ} \mathrm{C}$. Reactions were stopped by addition of $100 \mu \mathrm{L}$ DNS solution.

Agarase activity was estimated using agar and agarose (Sigma-Aldrich, Germany) as substrates. The assay contained a total volume of $100 \mu \mathrm{L}$ using $10-50 \mu \mathrm{L}$ of culture filtrates and $50 \mu \mathrm{L}$ of $0.25 \%$ substrate in $100 \mathrm{mM}$ sodium acetate buffer $\mathrm{pH}$ 5.0. The samples were incubated in microtiter plates for $24 \mathrm{~h}$ at $50{ }^{\circ} \mathrm{C}$. Reactions were stopped by addition of $100 \mu \mathrm{L}$ DNS solution.

Culture filtrates were also assayed using $p$-nitrophenol-linked substrates (4-nitrophenyl $\beta$-D-xylopyranoside, 4-nitrophenyl $\beta$-D-glucopyranoside, 4-nitrophenyl $\alpha$-L-fucopyranoside, potassium nitrophenyl sulphate; Sigma-Aldrich). The assays contained a total volume of $100 \mu \mathrm{L}$ using $10-50 \mu \mathrm{L}$ of the sample and $50 \mu \mathrm{L}$ of $2 \mathrm{mM}$-nitrophenol-linked substrates in $100 \mathrm{mM}$ sodium acetate buffer pH 5.0. Samples were incubated in microtiter plates for $30 \mathrm{~min}$ at $50{ }^{\circ} \mathrm{C}$. Reactions were stopped by addition of $100 \mu \mathrm{L} 0.5 \mathrm{M} \mathrm{Na}_{2} \mathrm{CO}_{3}$. Absorbance was measured at $405 \mathrm{~nm}$ in a microtiter plate reader.

The activities were calculated using a standard curve ranging from 0 to $2 \mathrm{~g} \cdot \mathrm{L}^{-1}$ glucose or ranging from 0 to $20 \mathrm{nM} p$-nitrophenol per assay volume for $p$-nitrophenol-linked substrates. Enzymatic 
activities results were expressed in $U$ of enzymatic activity where $1 \mathrm{U}$ corresponds to the amount of enzyme necessary to release $1 \mu \mathrm{mol}$ of equivalent reducing sugar or nitrophenol per minute of reaction. The data obtained are the results of two independent biological replicates and for each replicate three technical replicates were assayed.

\section{Results}

\subsection{Identification of the Fungal Isolates from Fucus sp.}

The twenty-two isolates that were obtained from Fucus sp. represented nine genera of the Ascomycota, three genera of the Basidiomycota and one genus of the Mucoromycota.

The taxonomic information given by the ITS and LSU sequences was insufficient to identify species level of the isolates with exception for Rhizopus oryzae (Table 1). Therefore, strains that had the best growth on algal biomass compared to glucose and wheat bran were further sequenced for species identification. Cladosporium sphaerospermum, Cladosporium ramotenellum, Cladosporium europaeum, and Epicoccum nigrum were identified based on TEF and ACT sequences, while Clonostachys rosea was identified based on BTUB (Table 1). Penicillium brevicompactum was identified using BTUB and CMD sequences, and Trichoderma paraviridescens was identified using only TEF (Table 1).

Table 1. Marine fungal isolates collected in this study.

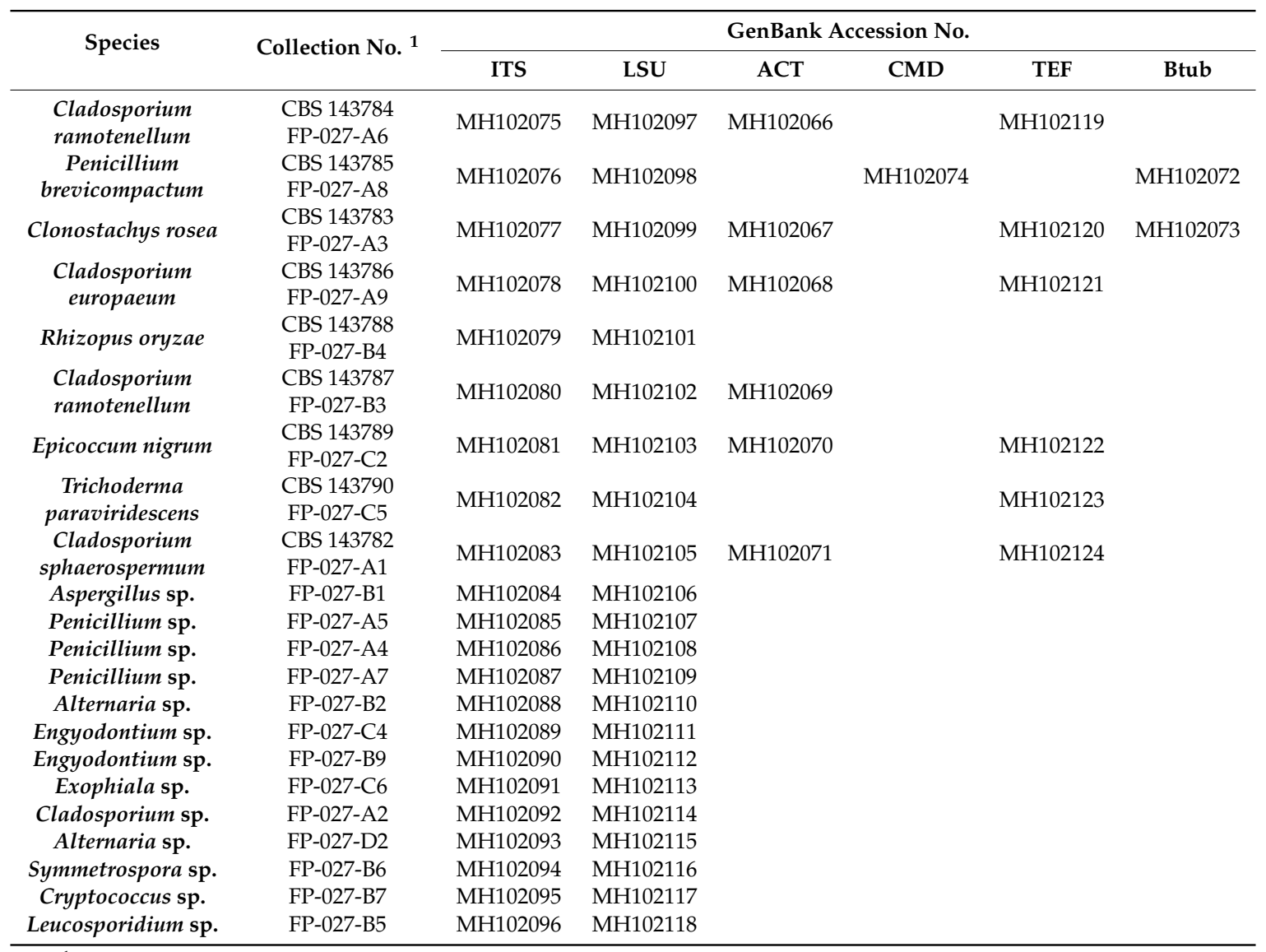

${ }^{1}$ CBS: culture collection of Westerdijk Fungal Biodiversity Institute, Utrecht, The Netherlands; FP: collection of Fugal Physiology group of Westerdijk Fungal Biodiversity Institute, Utrecht, The Netherlands. 


\subsection{Growth and Utilization of Algal Carbon Sources}

Fungal strains isolated from the brown seaweed Fucus $s p$. and two reference strains (A. nidulans FGSC A4 and A. sydowii CBS 593.65) were grown on minimal medium containing $1 \%$ of brown macroalgae F. vesiculosus and $1 \%$ of glucose as a control (Figure 1). Growth profiles showed that C. ramotenellum (two strains), P. brevicompactum, C. rosea, C. europaeum, $R$. oryzae, E. nigrum, T. paraviridescens, $C$. sphaerospermum grew better and denser on macroalgae than on glucose compared to the rest of the strains. A. sydowii CBS 593.65 grew similar on both substrates, while A. nidulans FGSC A4 had reduced growth on brown macroalgae (Figure 1).

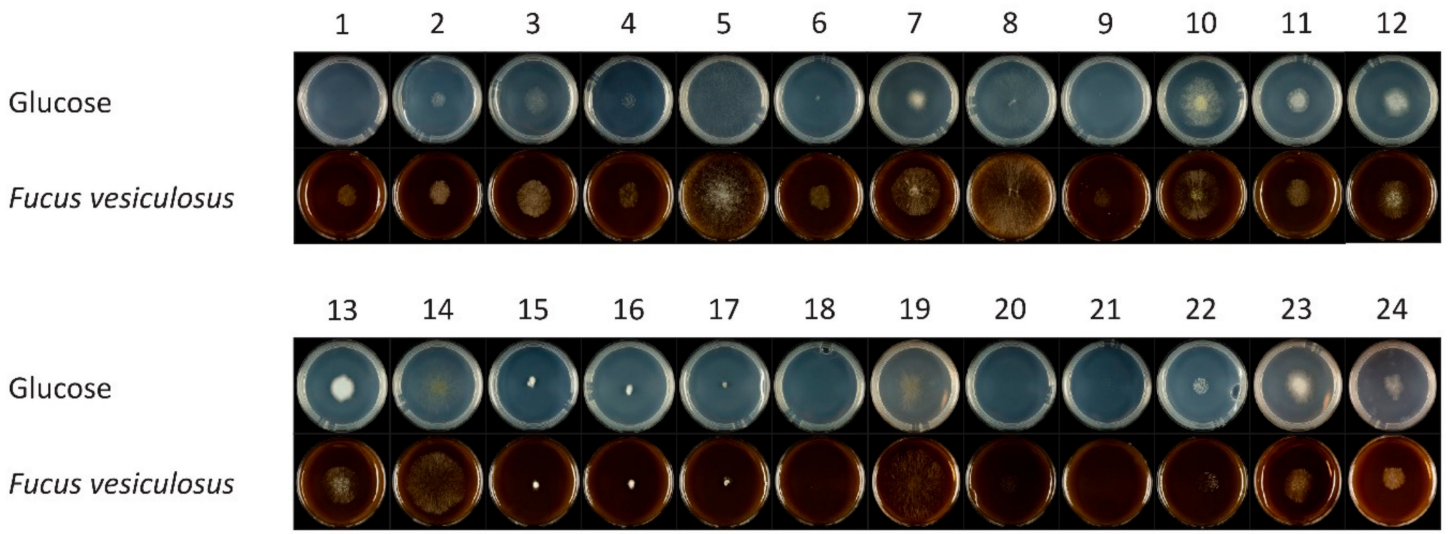

Figure 1. Growth of fungal strains isolated from brown seaweed Fucus sp. on glucose and brown seaweed, F. vesiculosus. 1: C. ramotenellum; 2: P. brevicompactum; 3: C. rosea; 4: C. europaeum; 5: $R$. oryzae; 6: C. ramotenellum; 7: E. nigrum; 8: T. paraviridescens; 9: C. sphaerospermum; 10: Aspergillus sp.; 11: Penicillium sp.; 12: Penicillium sp.; 13: Penicillium sp.; 14: Alternaria sp.; 15: Engyodontium sp.; 16: Engyodontium sp.; 17: Exophiala sp.; 18: Cladosporium sp.; 19: Alternaria sp.; 20: Symmetrospora sp.; 21: Cryptococcus sp.; 22: Leucosporidium sp.; 23: Aspergillus nidulans; 24: Aspergillus sydowii.

Strains that had better growth on brown seaweed F. vesiculosus were selected for more detailed growth analysis together with A. nidulans FGSC A4 and A. sydowii CBS 593.65. These strains were grown on minimal medium containing $1 \%$ brown seaweed (Fucus sp., F. vesiculosus, L. digitata, Saccharina sp., Sargassum sp.), or $1 \%$ green seaweed (U. lactuca). Fungal isolates were also grown on $1 \%$ wheat bran, $1 \%$ glucose, and $1 \%$ agar as a control. All selected strains had better growth on algal biomass compared to the growth on glucose and agar. However, they had similar growth on wheat bran and algal biomass (Figure 2). Interestingly, none of the selected fungal strains showed preference for any specific algae, but grew well on all algal substrates. R. oryzae, E. nigrum, and T. paraviridescens showed the best growth on all seaweeds, but grew equally well on wheat bran as a terrestrial strain A. nidulans (Figure 2). The preferred substrate for $A$. nidulans was wheat bran, while $A$. sydowii grew well on both plant and algal biomass. Growth profiles of four Cladosporium strains (C. europaeum, C. sphaerospermum and C. ramotenellum (two strains)) did not reveal significant differences in growth on seaweed biomass (Figure 2). C. europaeum was chosen to represent the Cladosporium group for growth in liquid media and further enzymatic analysis. 


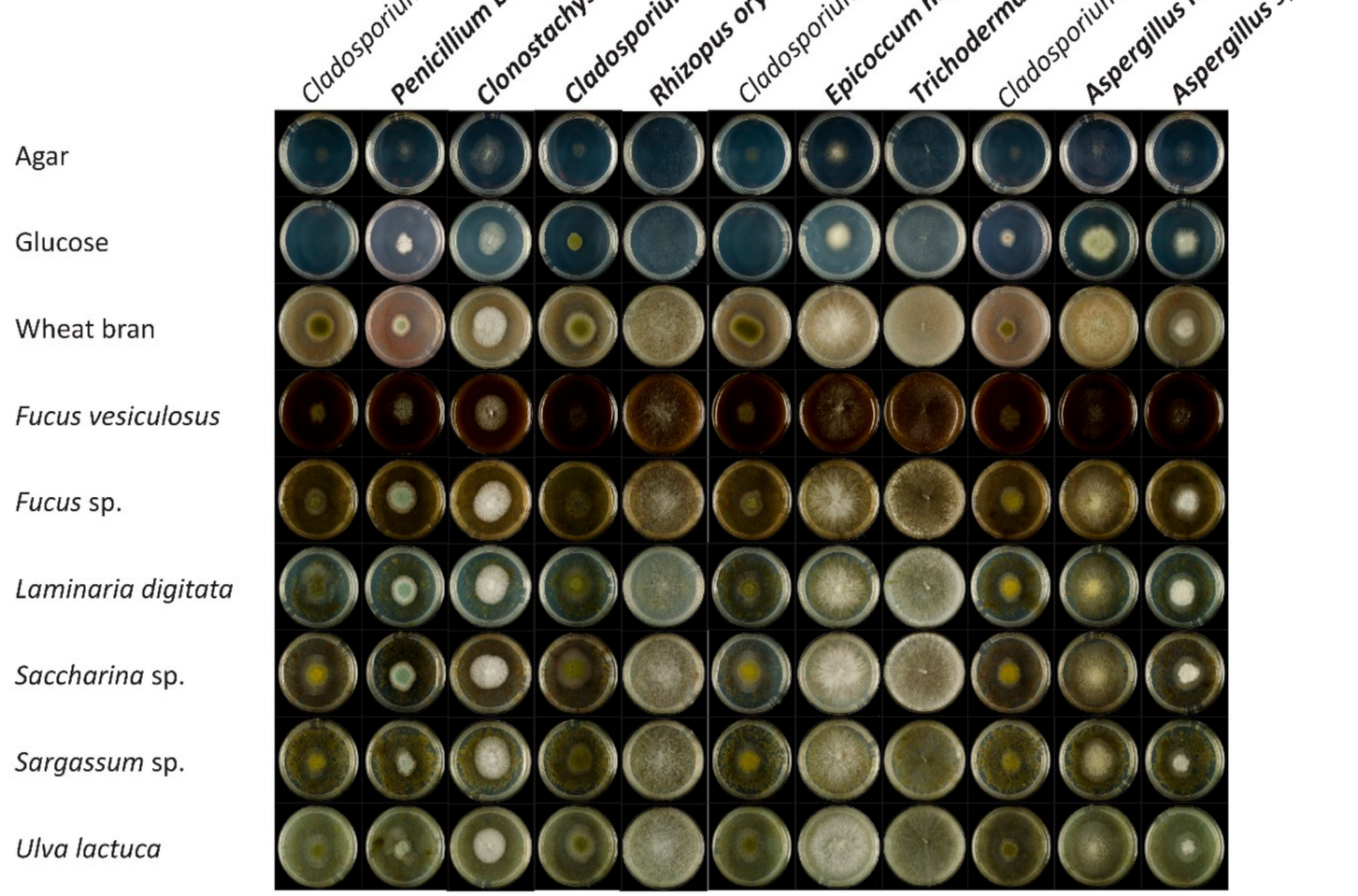

Figure 2. Growth of selected macroalgae derived strains on brown seaweed (Fucus sp., F. vesiculosus, L. digitata, Saccharina sp., Sargassum sp.) and green seaweed (U. lactuca). Strains that were further selected for evaluation of (hemi-)cellulolytic and algal specific enzymatic activities are in bold.

\subsection{Enzyme Activities during Growth on Seaweed and Plant Biomass Substrates}

Six strains (C. europaeum, E. nigrum, C. rosea, P. brevicompactum, T. paraviridescens, and R. oryzae) were evaluated for their (hemi-)cellulolytic and algal specific activities to better understand the abilities of marine fungi to degrade algal and terrestrial biomass. These strains and two reference strains $(A$. nidulans and A. sydowii) were grown on minimal media with green algae, $U$. lactuca, brown algae, $L$. digitata, alfalfa meal and corn powder as carbon source. Terrestrial biomass was included to assess whether isolated strains were able to degrade plant material by producing specific enzymes. In general, for all tested species the enzymatic activities increased over time (Figure 3).

(Hemi-)cellulolytic activities were measured against CMC, beechwood xylan, and $p$-nitrophenollinked substrates (4-nitrophenyl $\beta$-D-xylopyranoside and 4-nitrophenyl $\beta$-D-glucopyranoside). A high level of (hemi-)cellulolytic activities was detected during growth on terrestrial (alfalfa meal and corn powder) and algal biomass (green algae, $U$. lactuca and brown algae, L. digitata). Enzymes involved in cellulose degradation were detected on corn powder, alfalfa meal, $U$. lactuca and L. digitata in most of the species with the exception that there was no endoglucanase activity detected on L. digitata in P. brevicompactum, C. europaeum, and E. nigrum. However, $\beta$-glucosidase activity was detected in these strains grown on L. digitata. Moreover, xylanolytic enzymes were detected mainly on corn powder, alfalfa meal and $U$. lactuca. $R$. oryzae did not produce xylanolytic activities, except for $\beta$-xylosidases at a very low level after $60 \mathrm{~h}$ of cultivation. It has been shown that $R$. oryzae is not able to breakdown xylan significantly as it lacks essential xylanolytic enzymes (xylanases from GH10 or GH11 families), but the $R$. oryzae strain 99-880 genome contains family GH3 or GH43 candidate $\beta$-xylosidases [56,57]. However, it has been reported that $R$. oryzae strain NRRL 29086 produced xylanase activities when it was grown on wheat bran [58]. 
$60 \mathrm{~h}$

endoglucanase

- Alfalfa meal =Corn powder $\quad$ L. digitata $\quad$ U. lactuca

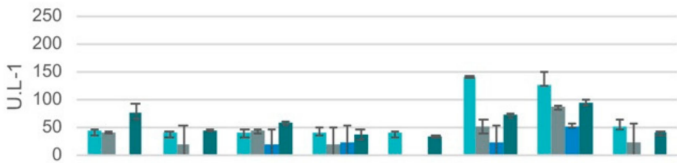

$\beta$-glucosidase

Alfalfa meal =Corn powder $\quad \mathrm{L}$. digitata $\quad=\mathrm{U}$. lactuca

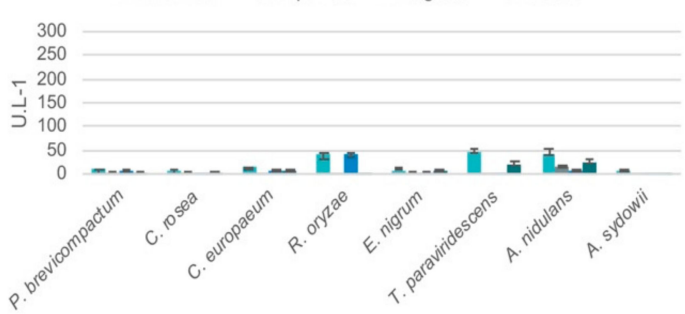

xylanase

-Alfalfa meal =Corn powder =L. digitata - U. lactuca

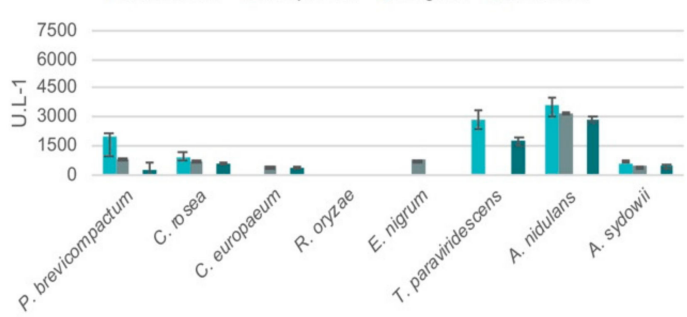

$\beta$-xylosidase

- Alfalfa meal Corn powder $L$. digitata U. lactuca

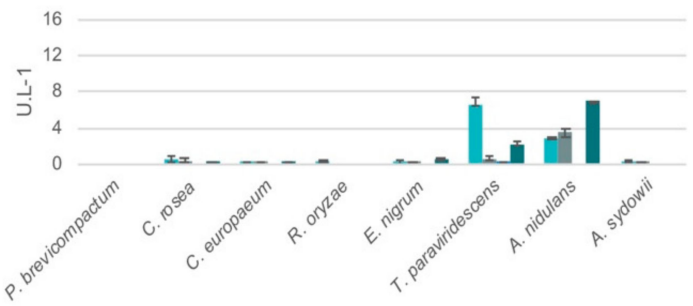

laminarinase

- Alfalfa meal =Corn powder -L digitata - U. lactuca

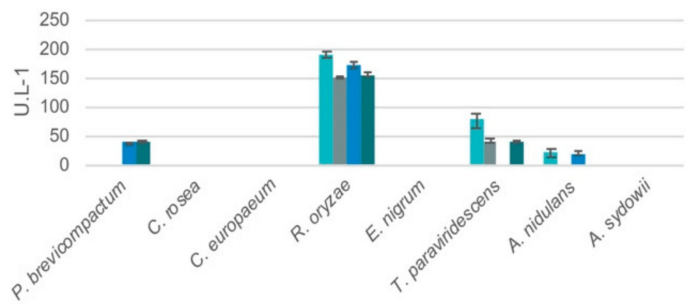

$120 \mathrm{~h}$

endoglucanase

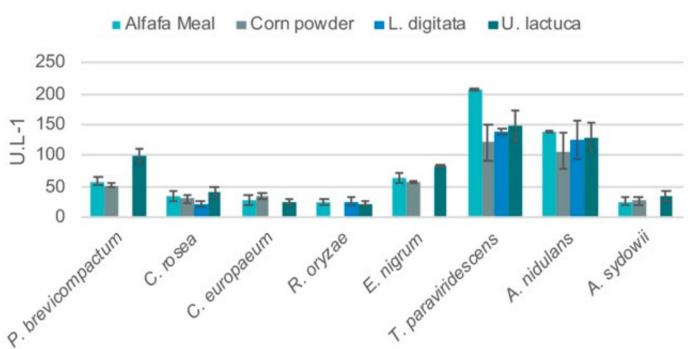

$\beta$-glucosidase

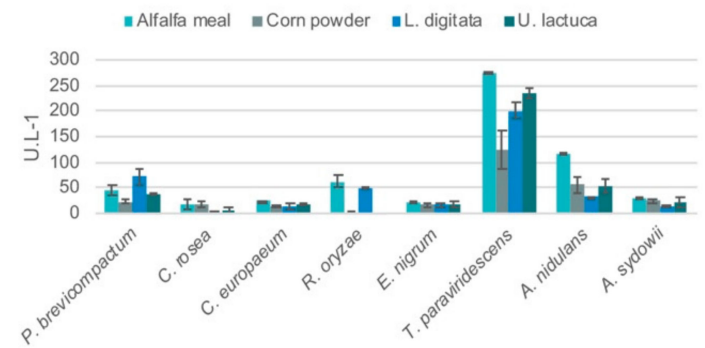

xylanase

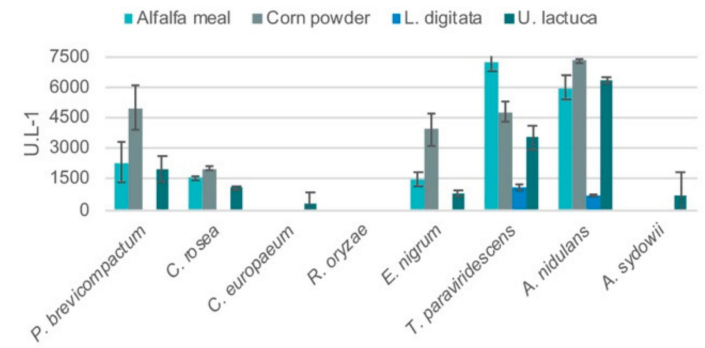

$\beta$-xylosidase

- Alfalfa meal $=$ Corn powder $\quad-$ L. digitata $\quad-U$. lactuca

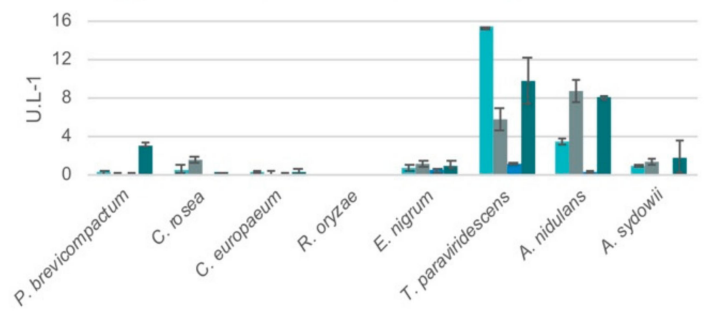

laminarinase

- Alfalfa meal $=$ Corn powder $\quad-\mathrm{L}$. digitata $\quad-\mathrm{U}$. lactuca

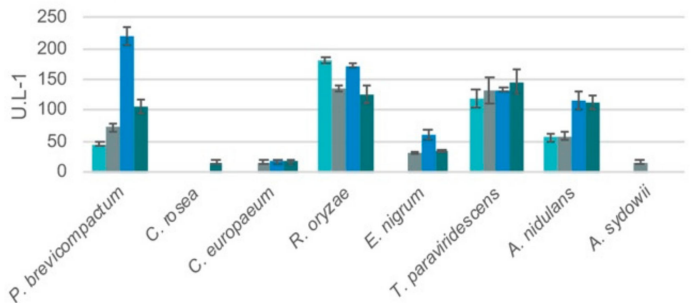

Figure 3. Cont. 
$60 \mathrm{~h}$

carrageenase

-Alfalfa meal =Corn powder - L. digitata -U. lactuca

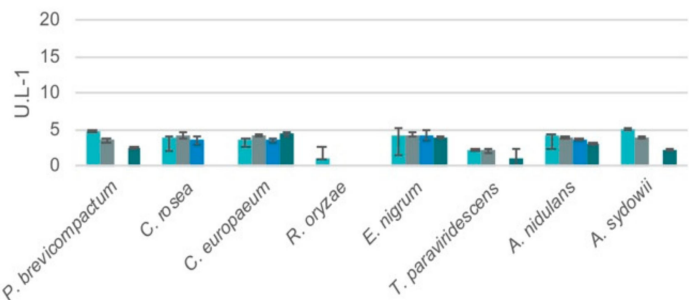

fucoidanase

-Alfalfa meal =Corn powder -L. digitata -U. lactuca

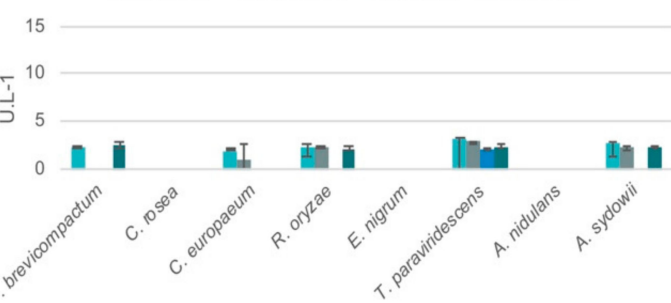

alginase

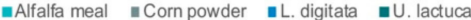

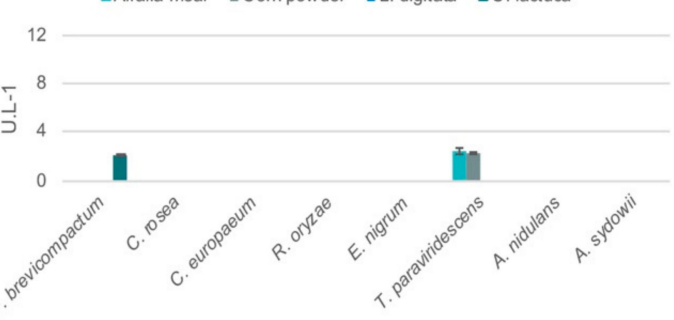

agarase (substrate-agar)

-Alfalfa meal Corn powder $\quad$ L. digitata U. lactuca
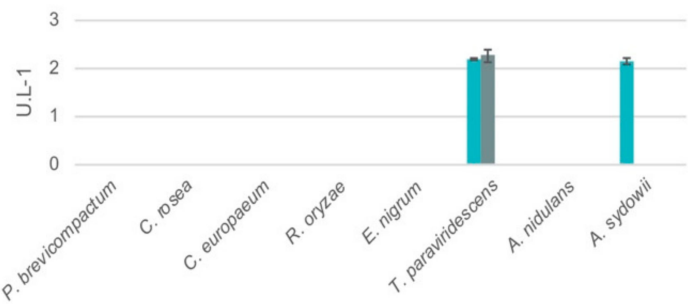

agarase (substrate-agarose)

- Alfalfa meal =Corn powder $\quad$ - L. digitata $\quad$-U. lactuca

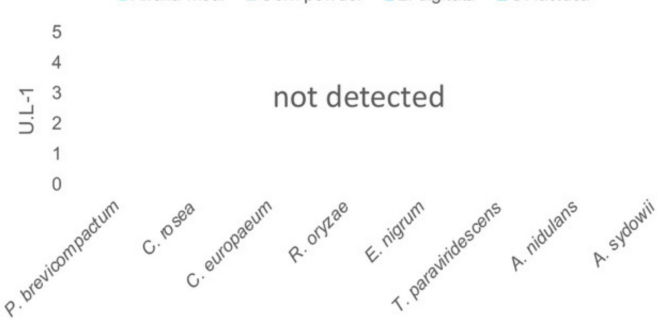

$120 \mathrm{~h}$

carrageenase

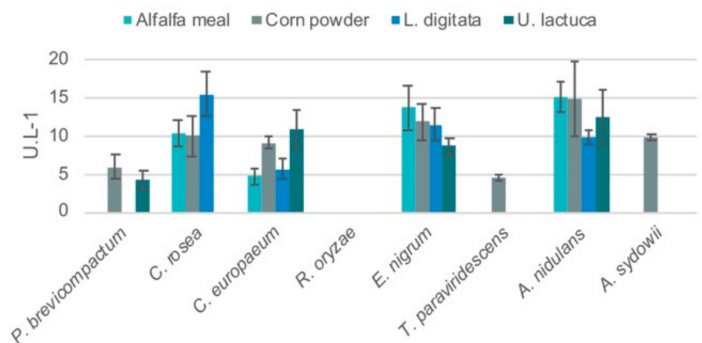

fucoidanase

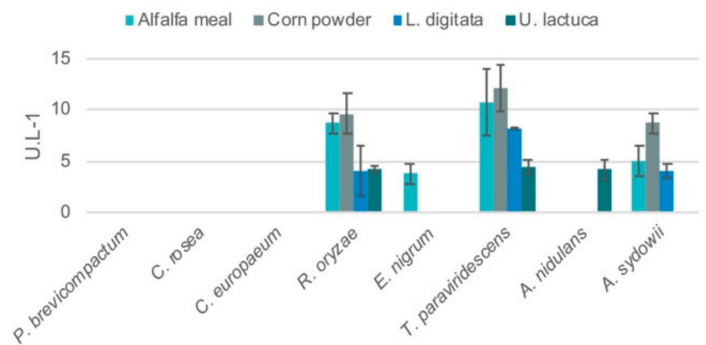

alginase

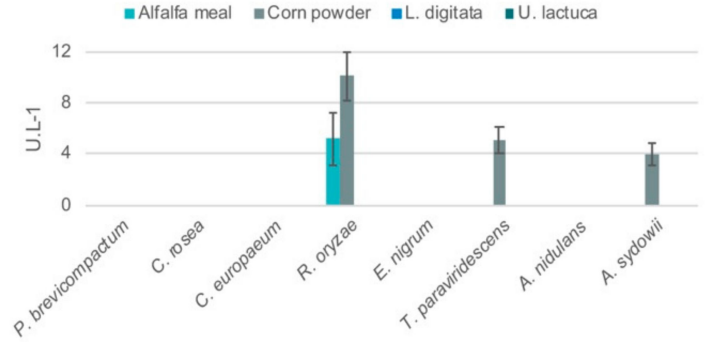

agarase (substrate-agar)

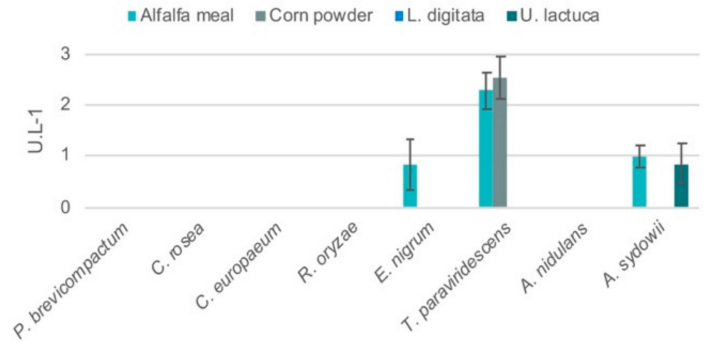

agarase (substrate-agarose)

- Alfalfa meal - Corn powder - L, digitata -U. lactuca

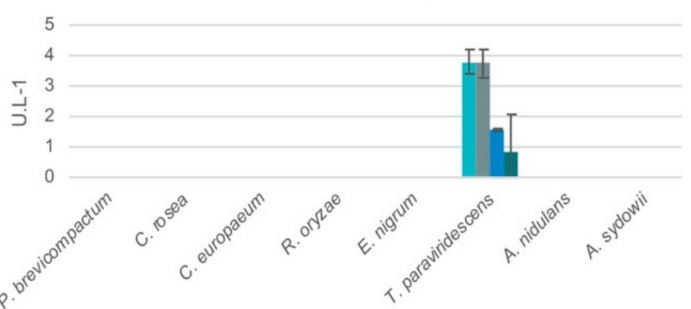

Figure 3. Algal and plant biomass degrading enzyme activities produced by macroalgae derived fungi during growth on seaweed and plant biomass substrates. The error bars indicate the standard deviation of two biological replicate flask cultivations and three technical replicate reactions. 
T. paraviridescens produced the highest endoglucanase and $\beta$-glucosidase activities after $120 \mathrm{~h}$ of growth on plant and algal biomass. The highest xylanase activity was produced by E. nigrum, P. brevicompactum, T. paraviridescens after growth for $120 \mathrm{~h}$ on plant and algal biomass. As observed for endoglucanase and $\beta$-glucosidase activities, the highest xylanase and $\beta$-xylosidase activities were produced by T. paraviridescens. Although the terrestrial $A$. nidulans produced high levels of (hemi-)cellulolytic activities, the macroalgae isolate T. paraviridescens produced higher endoglucanase and $\beta$-glucosidase activities on all tested substrates, and higher xylanase and $\beta$-xylosidase on alfalfa meal after $120 \mathrm{~h}$ (Figure 3).

To examine whether isolated marine fungi were capable of degrading seaweed polysaccharides, laminarinase, alginase, carrageenase, fucoidanase, agarase, and sulfatase activities were measured. All fungi were able to produce enzymes involved in algal biomass degradation. However, the production of these activities was lower in comparison with production of cellulases and hemicellulases. Laminarinase (endo- $\beta-1,3$-glucanase) activity was detected at the highest levels both on algal and plant biomass. The highest laminarinase activities were produced by P. brevicompactum, T. paraviridescens and R. oryzae. It has been shown that Emericellopsis and Acremonium species isolated from the brown seaweed Fucus spp. produced laminarinase activities when grown on laminarin [34]. A. nidulans was also able to produce laminarinase activities at good levels on all substrates. Furthermore, it produced carrageenase activities at the highest levels on all substrates except for L. digitata compared to the isolated from macroalgae strains. In contrast, $A$. sydowii, with marine and terrestrial lifestyles, did not produce high levels of enzymatic activities involved in algal or plant polysaccharides degradation. This correlates well with the growth profile of $A$. sydowii, as it grew similar well on all tested carbon sources and did not show any outstanding growth.

\section{Discussion}

In the present study, we have explored the macroalgal biomass degrading potential of marine fungi isolated from the brown seaweed Fucus sp. The obtained information serves as a source for deciphering the aquatic carbon cycle by marine fungi and exploitation of enzymes involved in seaweed degradation. We have performed isolation and identification of fungal species collected from Fucus sp., their ability to grow on different carbohydrates, and correlated the measured enzyme activities to growth on green algae (U. lactuca), brown algae (L. digitate), alfalfa meal, and corn powder. Our study shows that several macroalgae derived fungi obtained from Fucus sp. are able to degrade algal polymers and have furthermore the ability to grow on terrestrial biomass and produce enzymes involved in degradation of plant cell wall polysaccharides.

Analysis of the sequencing results of ITS and LSU regions of fungi isolated from the brown seaweed Fucus sp. revealed thirteen different genera: Cladosporium, Penicillium, Clonostachys, Rhizopus, Epicoccum, Trichoderma, Aspergillus, Alternaria, Engyodontium, Exophiala, Symmetrospora, Cryptococcus, and Leucosporidium. Previous studies have shown similar fungal genera associated with the brown seaweeds F. vesiculosus (Aspergillus, Coniothyrium, Penicillium, Alternaria) [59], Fucus spiralis (Penicillium), Fucus serratus (Lindra, Lulworthia, Engyodontium, Sigmoidea/Corollospora complex, Emericellopsis/Acremonium-like ribotypes [32] and Aspergillus, Coniothyrium, Penicillium [59]). Cladosporium isolates were dominantly present on the surface of the brown seaweed Fucus sp. It was expected as the most frequently isolated genus in marine environment is Cladosporium [60]. In addition, all seaweed derived isolates identified in this study are facultative marine fungi and can be found in marine and terrestrial ecosystems. For instance, C. sphaerospermum [61], C. ramotenellum [62], P. brevicompactum [63], E. nigrum [62], C. rosea [64], and R. oryzae [65] are mainly known from terrestrial environments, but they are also found in deep sea (C. sphaerospermum) [66], Dead Sea water (C. ramotenellum, P. brevicompactum) [67], river sediments (C. rosea) [68], associated with marine sponges (E. nigrum, P. brevicompactum) [69,70], bryozoan Bugula sp. (R. oryzae) [71] or with seagrasses Posidonia oceanica (C. rosea) [72]. To the best of our knowledge, this is the first study that isolated T. paraviridescens from a marine environment. However, other species 
of Trichoderma have previously been found in marine sediments, marine sponges, mangroves, brown algae [72-74].

The growth profile data showed a clear preference of C. ramotenellum, P. brevicompactum, C. rosea, C. europaeum, R. oryzae, E. nigrum, T. paraviridescens, C. sphaerospermum towards the brown seaweed F. vesiculosus in comparison with their growth on glucose. These isolates grew well on brown and green algal biomass, indicating no preference for any specific algae. The chemical composition of green and brown algae differs significantly [4-7], suggesting that isolated species have a broad arsenal of enzymes to degrade algal biomass. Moreover, Cladosporium (C. sphaerospermum, Cladosporium cladosporioides) and Penicillium (P. brevicompactum, Penicillium antarcticum) species were found associated with both green and brown algae $[29,75]$. The two reference strains, a terrestrial ascomycete $A$. nidulans and a facultative marine fungus $A$. sydowii, were included in this study to assess physiological differences between isolated marine fungi and well-studied strains with different life styles. A. nidulans is a model fungus that is naturally found in the rhizosphere and is commonly used to study the regulation and secretion of lignocellulolytic enzymes [76]. In contrast, A. sydowii has both a terrestrial and a marine life style, and produces a broad range of lignocellulolytic enzymes [77]. When assessing growth of the two reference strains on terrestrial and algal biomass, similar growth of $A$. sydowii on wheat bran and green or brown algae and clear preference of $A$. nidulans towards wheat bran were observed. This could be explained by the dual life style of $A$. sydowii, while $A$. nidulans is used to utilizing mainly a terrestrial carbon. Notably, when comparing the growth of terrestrial strain $A$. nidulans on wheat bran with Fucus sp derived strains, similar good growth was also observed for R. oryzae, E. nigrum, and T. paraviridescens. These fungi also colonize terrestrial environments, for instance, $R$. oryzae was isolated from rice hull [78], E. nigrum is a litter and leaf decaying fungus [79], and T. paraviridescens was found on decaying wood [80]. This indicates that these species are widely spread in the terrestrial and marine environment and possibly have a significant role in aquatic and plant biomass degradation. The absence of algal biomass degrading ability in $A$. nidulans together with general terrestrial biomass degradation ability in all tested strains, suggests that terrestrial fungi have lost their ability to degrade marine biomass, or alternatively that the marine isolates have gained their ability to degrade marine biomass upon re-colonizing a marine biotope.

Our analyses examined enzymatic potential of isolated strains grown on corn powder, alfalfa meal, green seaweed $U$. lactuca and brown seaweed L. digitata, with focus on the production of plant and algal biomass degrading enzymes. These included enzymes involved in cellulose and xylan (endoglucanase, $\beta$-glucosidase, xylanase, and $\beta$-xylosidase) and in seaweed polysaccharides (laminarinase, alginase, carrageenase, fucoidanase, agarase, and sulfatase) degradation. The measured enzyme activities were generally in good agreement with the composition of tested substrates confirming that enzymes involved in the degradation of specific polysaccharides would therefore be expected in the culture filtrate of species grown on the substrates consisted of these polysaccharides. Corn powder and alfalfa meal mainly consist of cellulose, xylan, starch, arabinan, and lignin with cellulose and xylan representing the major part of the cell wall [81,82]. In contrast to terrestrial biomass, green seaweed $U$. lactuca contains four polysaccharide families: two major ones, ulvan and cellulose, and two minor ones, xyloglucan and a glucuronan [5], while brown seaweed L. digitata carbohydrate components include cellulose, laminarin, alginate, and mannitol [4,12]. Most of the strains were able to produce cellulose degrading enzymes on corn powder, alfalfa meal, U. lactuca and L. digitata, while xylan degrading enzymatic activities were detected mainly on corn powder, alfalfa meal, and U. lactuca. It is not surprising that seaweed derived T. paraviridescens had the highest (hemi-)cellulolytic activities, as several Trichoderma species are known to be good producers of (hemi-)cellulolytic enzymes [83,84].

Based on seaweed polysaccharides degrading enzyme activities measurements, it seemed that there was no correlation between the production of seaweed specific enzymes and the carbon sources tested. Moreover, the marine isolated fungi showed an average capacity to secrete enzymes for the degradation of algal biomass, although these isolates had good growth on brown and green algal biomass. This could be explained by their ability to produce high cellulases and xylanase as 
these polysaccharides are also important components of the algal cell wall. Possibly, lower levels of enzymes targeting the algal specific polysaccharides already facilitate access to the more common polymers. However, it could also demonstrate our poor understanding of the enzymes involved in algal biomass degradation, as only a small number of enzymes have been identified in contrast to the extensive set that is known for plant biomass. The data obtained here show the existence of different enzymatic approaches to degrade algal biomass. Future cultivation of marine fungi on purified algal polysaccharides such as laminarin, alginate, and carrageenan could give better insights into the mechanisms of utilization of algal carbon by marine derived fungi.

Author Contributions: A.P., D.L.F., and A.W. performed the experiments. A.P. and D.L.F. analyzed the data. A.P. drafted the manuscript. R.P.d.V. designed the study. R.P.d.V and K.T. reviewed the manuscript. All authors approved the final manuscript. All authors have read and agreed to the published version of the manuscript.

Funding: This research received no external funding. D.L.F. was supported Conselho Nacional de Pesquisa e Desenvolvimento Científico (CNPq) with grant number 246763/2012-4.

Acknowledgments: We thank Ewald Groenewald for help with identification of the Cladosporium group and preparing files for the GenBank submission.

Conflicts of Interest: The authors declare no conflict of interest.

\section{References}

1. Masarin, F.; Cedeno, F.R.; Chavez, E.G.; de Oliveira, L.E.; Gelli, V.C.; Monti, R. Chemical analysis and biorefinery of red algae Kappaphycus alvarezii for efficient production of glucose from residue of carrageenan extraction process. Biotechnol. Biofuels 2016, 9, 1-12. [CrossRef] [PubMed]

2. Rodrigues, D.; Sousa, S.; Silva, A.; Amorim, M.; Pereira, L.; Rocha-Santos, T.A.P.; Gomes, A.M.P.; Duarte, A.C.; Freitas, A.C. Impact of enzyme- and ultrasound-assisted extraction methods on biological properties of red, brown, and green seaweeds from the central west coast of Portugal. J. Agric. Food Chem. 2015, 63, 3177-3188. [CrossRef] [PubMed]

3. Maehre, H.K.; Jensen, I.J.; Eilertsen, K.E. Enzymatic pre-treatment increases the protein bioaccessibility and extractability in dulse (Palmaria palmata). Mar. Drugs 2016, 14, 196. [CrossRef] [PubMed]

4. Deniaud-Bouët, E.; Hardouin, K.; Potin, P.; Kloareg, B.; Hervé, C. A review about brown algal cell walls and fucose-containing sulfated polysaccharides: Cell wall context, biomedical properties and key research challenges. Carbohydr. Polym. 2017, 175, 395-408. [CrossRef]

5. Lahaye, M.; Robic, A. Structure and functional properties of ulvan, a polysaccharide from green seaweeds. Biomacromolecules 2007, 8, 1765-1774. [CrossRef]

6. Jiménez-Escrig, A.; Gómez-Ordóñez, E.; Rupérez, P. Infrared characterisation, monosaccharide profile and antioxidant activity of chemical fractionated polysaccharides from the edible seaweed sugar Kombu (Saccharina latissima). Int. J. Food Sci. Technol. 2015, 50, 340-346. [CrossRef]

7. Kloareg, B.; Quatrano, R. Structure of the cell walls of marine algae and ecophysiological functions of the matrix polysaccharides. Oceanogr. Mar. Biol. 1988, 26, 259-315.

8. Zhang, X.; Thomsen, M. Biomolecular composition and revenue explained by interactions between extrinsic factors and endogenous rhythms of Saccharina latissima. Mar. Drugs 2019, 17, 107. [CrossRef]

9. Fiset, C.; Irwin, A.J.; Finkel, Z.V. The macromolecular composition of noncalcified marine macroalgae. J. Phycol. 2019, 55, 1361-1369. [CrossRef]

10. Abdel-Fattah, A.; Edrees, M. Seasonal changes in the constituents of Ulva lactuca. Phytochemistry 1973, 12, 481-485. [CrossRef]

11. Khairy, H.M.; El-Shafay, S.M. Seasonal variations in the biochemical composition of some common seaweed species from the coast of Abu Qir Bay, Alexandria, Egypt. Oceanologia 2013, 55, 435-452. [CrossRef]

12. Schiener, P.; Black, K.D.; Stanley, M.S.; Green, D.H. The seasonal variation in the chemical composition of the kelp species Laminaria digitata, Laminaria hyperborea, Saccharina latissima and Alaria esculenta. J. Appl. Phycol. 2015, 27, 363-373. [CrossRef]

13. Manns, D.; Nielsen, M.M.; Bruhn, A.; Saake, B.; Meyer, A.S. Compositional variations of brown seaweeds Laminaria digitata and Saccharina latissima in Danish waters. J. Appl. Phycol. 2017, 29, 1493-1506. [CrossRef] 
14. Vermaas, J.V.; Petridis, L.; Qi, X.; Schulz, R.; Lindner, B.; Smith, J.C. Mechanism of lignin inhibition of enzymatic biomass deconstruction. Biotechnol. Biofuels 2015, 8, 1-16. [CrossRef] [PubMed]

15. Studer, M.H.; DeMartini, J.D.; Davis, M.F.; Sykes, R.W.; Davison, B.; Keller, M.; Tuskan, G.A.; Wyman, C.E. Lignin content in natural Populus variants affects sugar release. Proc. Natl. Acad. Sci. USA 2011, 108, 6300-6305. [CrossRef]

16. Si, S.; Chen, Y.; Fan, C.; Hu, H.; Li, Y.; Huang, J.; Liao, H.; Hao, B.; Li, Q.; Peng, L.; et al. Lignin extraction distinctively enhances biomass enzymatic saccharification in hemicelluloses-rich Miscanthus species under various alkali and acid pretreatments. Bioresour. Technol. 2015, 183, 248-254. [CrossRef]

17. Barbarino, E.; Lourenço, S.O. An evaluation of methods for extraction and quantification of protein from marine macro- and microalgae. J. Appl. Phycol. 2005, 17, 447-460. [CrossRef]

18. Harnedy, P.A.; FitzGerald, R.J. Extraction of protein from the macroalga Palmaria palmata. LWT-Food Sci. Technol. 2013, 51, 375-382. [CrossRef]

19. Polikovsky, M.; Fernand, F.; Sack, M.; Frey, W.; Müller, G.; Golberg, A. Towards marine biorefineries: Selective proteins extractions from marine macroalgae Ulva with pulsed electric fields. Innov. Food Sci. Emerg. Technol. 2016, 37, 194-200. [CrossRef]

20. Hardouin, K.; Bedoux, G.; Burlot, A.-S.; Donnay-Moreno, C.; Bergé, J.-P.; Nyvall-Collén, P.; Bourgougnon, N. Enzyme-assisted extraction (EAE) for the production of antiviral and antioxidant extracts from the green seaweed Ulva armoricana (Ulvales, Ulvophyceae). Algal Res. 2016, 16, 233-239. [CrossRef]

21. Charoensiddhi, S.; Franco, C.; Su, P.; Zhang, W. Improved antioxidant activities of brown seaweed Ecklonia radiata extracts prepared by microwave-assisted enzymatic extraction. J. Appl. Phycol. 2015, 27, 2049-2058. [CrossRef]

22. Tisthammer, K.H.; Cobian, G.M.; Amend, A.S. Global biogeography of marine fungi is shaped by the environment. Fungal Ecol. 2016, 19, 39-46. [CrossRef]

23. Raghukumar, S. The marine environment and the role of fungi. In Fungi in Coastal and Oceanic Marine Ecosystems: Marine Fungi; Springer International Publishing: Cham, Switzerland, 2017; pp. 17-38. [CrossRef]

24. Jones, E.B.G.; Suetrong, S.; Sakayaroj, J.; Bahkali, A.H.; Abdel-Wahab, M.A.; Boekhout, T.; Pang, K.-L. Classification of marine Ascomycota, Basidiomycota, Blastocladiomycota and Chytridiomycota. Fungal Divers. 2015, 73, 1-72. [CrossRef]

25. Debbab, A.; Aly, A.H.; Proksch, P. Mangrove derived fungal endophytes-a chemical and biological perception. Fungal Divers. 2013, 61, 1-27. [CrossRef]

26. Overy, D.P.; Bayman, P.; Kerr, R.G.; Bills, G.F. An assessment of natural product discovery from marine (sensu strictu) and marine-derived fungi. Mycology 2014, 5, 145-167. [CrossRef] [PubMed]

27. Flewelling, A.J.; Currie, J.; Gray, C.A.; Johnson, J.A. Endophytes from marine macroalgae: Promising sources of novel natural products. Curr. Sci. 2015, 109, 88-111.

28. Miao, F.; Zuo, J.; Liu, X.; Ji, N. Algicidal activities of secondary metabolites of marine macroalgal-derived endophytic fungi. J. Oceanol. Limnol. 2019, 37, 112-121. [CrossRef]

29. Gnavi, G.; Garzoli, L.; Poli, A.; Prigione, V.; Burgaud, G.; Varese, G.C. The culturable mycobiota of Flabellia petiolata: First survey of marine fungi associated to a Mediterranean green alga. PLoS ONE 2017, 12, e0175941. [CrossRef]

30. Kohlmeyer, J.; Volkmann-Kohlmeyer, B. Illustrated key to the filamentous higher marine fungi. Bot. Mar. 1991, 34, 1-61. [CrossRef]

31. Stanley, S.J. Observations on the seasonal occurrence of marine endophytic and parasitic fungi. Can. J. Bot. 1992, 70, 2089-2096. [CrossRef]

32. Zuccaro, A.; Schoch, C.L.; Spatafora, J.W.; Kohlmeyer, J.; Draeger, S.; Mitchell, J.I. Detection and identification of fungi intimately associated with the brown seaweed Fucus serratus. Appl. Environ. Microbiol. 2008, 74, 931-941. [CrossRef] [PubMed]

33. Lee, S.; Park, M.S.; Lee, H.; Kim, J.J.; Eimes, J.A.; Lim, Y.W. Fungal diversity and enzyme activity associated with the macroalgae, Agarum clathratum. Mycobiology 2019, 47, 50-58. [CrossRef] [PubMed]

34. Zuccaro, A.; Summerbell, R.C.; Gams, W.; Schroers, H.-J.; Mitchell, J.I. A new Acremonium species associated with Fucus spp., and its affinity with a phylogenetically distinct marine Emericellopsis clade. Stud. Mycol. 2004, 50, 283-297.

35. Kohlmeyer, J.; Kohlmeyer, E. Marine Mycology: The Higher Fungi; Elsevier: Amsterdam, The Netherlands, 2013. 
36. Wainwright, B.J.; Bauman, A.G.; Zahn, G.L.; Todd, P.A.; Huang, D. Characterization of fungal biodiversity and communities associated with the reef macroalga Sargassum ilicifolium reveals fungal community differentiation according to geographic locality and algal structure. Mar. Biodivers. 2019, 49, 2601-2608. [CrossRef]

37. Mäkelä, M.R.; Donofrio, N.; de Vries, R.P. Plant biomass degradation by fungi. Fungal Genet. Biol. 2014, 72, 2-9. [CrossRef]

38. Peterson, R.; Nevalainen, H. Trichoderma reesei RUT-C30-thirty years of strain improvement. Microbiology 2012, 158, 58-68. [CrossRef]

39. De Vries, R.P.; Visser, J. Aspergillus enzymes involved in degradation of plant cell wall polysaccharides. Microbiol. Mol. Biol. Rev. 2001, 65, 497-522. [CrossRef]

40. Wei, N.; Quarterman, J.; Jin, Y.-S. Marine macroalgae: An untapped resource for producing fuels and chemicals. Trends Biotechnol. 2013, 31, 70-77. [CrossRef]

41. Gao, K.; McKinley, K.R. Use of macroalgae for marine biomass production and $\mathrm{CO}_{2}$ remediation: A review. J. Appl. Phycol. 1994, 6, 45-60. [CrossRef]

42. John, R.P.; Anisha, G.; Nampoothiri, K.M.; Pandey, A. Micro and macroalgal biomass: A renewable source for bioethanol. Bioresour. Technol. 2011, 102, 186-193. [CrossRef]

43. Balabanova, L.; Slepchenko, L.; Son, O.; Tekutyeva, L. Biotechnology potential of marine fungi degrading plant and algae polymeric substrates. Front. Microbiol. 2018, 9, 15-27. [CrossRef] [PubMed]

44. Galagan, J.E.; Calvo, S.E.; Cuomo, C.; Ma, L.-J.; Wortman, J.R.; Batzoglou, S.; Lee, S.-I.; Baştürkmen, M.; Spevak, C.C.; Clutterbuck, J.; et al. Sequencing of Aspergillus nidulans and comparative analysis with $A$. fumigatus and A. oryzae. Nature 2005, 438, 1105-1115. [CrossRef] [PubMed]

45. Ein-Gil, N.; Ilan, M.; Carmeli, S.; Smith, G.W.; Pawlik, J.R.; Yarden, O. Presence of Aspergillus sydowii, a pathogen of gorgonian sea fans in the marine sponge Spongia obscura. ISME J. 2009, 3, 752-755. [CrossRef]

46. De Vries, R.P.; Burgers, K.; van de Vondervoort, P.J.; Frisvad, J.C.; Samson, R.A.; Visser, J. A new black Aspergillus species, A. vadensis, is a promising host for homologous and heterologous protein production. Appl. Environ. Microbiol. 2004, 70, 3954-3959. [CrossRef] [PubMed]

47. De Hoog, G.S.; Gerrits van den Ende, A.H.G. Molecular diagnostics of clinical strains of filamentous Basidiomycetes. Mycoses 1998, 41, 183-189. [CrossRef]

48. Vilgalys, R.; Hester, M. Rapid genetic identification and mapping of enzymatically amplified ribosomal DNA from several Cryptococcus species. J. Bacteriol. 1990, 172, 4238-4246. [CrossRef]

49. Boekhout, T.; Theelen, B.; Houbraken, J.; Robert, V.; Scorzetti, G.; Gafni, A.; Gerson, U.; Sztejnberg, A. Novel anamorphic mite-associated fungi belonging to the Ustilaginomycetes: Meira geulakonigii gen. nov., sp. nov., Meira argovae sp. nov. and Acaromyces ingoldii gen. nov., sp. nov. Int. J. Syst. Evol. Microbiol. 2003, 53, 1655-1664. [CrossRef]

50. Glass, N.L.; Donaldson, G.C. Development of primer sets designed for use with the PCR to amplify conserved genes from filamentous ascomycetes. Appl. Environ. Microbiol. 1995, 61, 1323-1330.

51. Carbone, I.; Kohn, L.M. A method for designing primer sets for speciation studies in filamentous ascomycetes. Mycologia 1999, 91, 553-556. [CrossRef]

52. Hong, S.-B.; Cho, H.-S.; Shin, H.-D.; Frisvad, J.C.; Samson, R.A. Novel Neosartorya species isolated from soil in Korea. Int. J. Syst. Evol. Microbiol. 2006, 56, 477-486. [CrossRef]

53. Peterson, S.W.; Bayer, E.M.; Wicklow, D.T. Penicillium thiersii, Penicillium angulare and Penicillium decaturense, new species isolated from wood-decay fungi in North America and their phylogenetic placement from multilocus DNA sequence analysis. Mycologia 2004, 96, 1280-1293. [CrossRef] [PubMed]

54. Groenewald, M.; Groenewald, J.Z.; Crous, P.W. Distinct species exist within the Cercospora apii morphotype. Phytopathology 2005, 95, 951-959. [CrossRef] [PubMed]

55. White, T.J.; Bruns, T.; Lee, S.; Taylor, J. Amplification and direct sequencing of fungal ribosomal RNA genes for phylogenetics. In PCR Protocols: A Guide to Methods and Applications; Innis, M.A., Gelfand, D.H., Sninsky, J.J., White, T.J., Eds.; Academic Press: San Diego, CA, USA, 1990; Volume 18, pp. 315-322.

56. Battaglia, E.; Benoit, I.; van den Brink, J.; Wiebenga, A.; Coutinho, P.M.; Henrissat, B.; de Vries, R.P. Carbohydrate-active enzymes from the zygomycete fungus Rhizopus oryzae: A highly specialized approach to carbohydrate degradation depicted at genome level. BMC Genom. 2011, 12, 38. [CrossRef] [PubMed]

57. Ma, L.-J.; Ibrahim, A.S.; Skory, C.; Grabherr, M.G.; Burger, G.; Butler, M.; Elias, M.; Idnurm, A.; Lang, B.F.; Sone, T. Genomic analysis of the basal lineage fungus Rhizopus oryzae reveals a whole-genome duplication. PLoS Genet. 2009, 5, e1000549. [CrossRef] 
58. Xiao, Z.; Grosse, S.; Bergeron, H.; Lau, P.C. Cloning and characterization of the first GH10 and GH11 xylanases from Rhizopus oryzae. Appl. Microbiol. Biotechnol. 2014, 98, 8211-8222. [CrossRef]

59. Flewelling, A.J.; Johnson, J.A.; Gray, C.A. Isolation and bioassay screening of fungal endophytes from North Atlantic marine macroalgae. Bot. Mar. 2013, 56, 287-297. [CrossRef]

60. Panno, L.; Bruno, M.; Voyron, S.; Anastasi, A.; Gnavi, G.; Miserere, L.; Varese, G.C. Diversity, ecological role and potential biotechnological applications of marine fungi associated to the seagrass Posidonia oceanica. New Biotechnol. 2013, 30, 685-694. [CrossRef]

61. Hamayun, M.; Afzal Khan, S.; Ahmad, N.; Tang, D.-S.; Kang, S.-M.; Na, C.-I.; Sohn, E.-Y.; Hwang, Y.-H.; Shin, D.-H.; Lee, B.-H.; et al. Cladosporium sphaerospermum as a new plant growth-promoting endophyte from the roots of Glycine max (L.) Merr. World J. Microbiol. Biotechnol. 2009, 25, 627-632. [CrossRef]

62. Lorenzini, M.; Zapparoli, G. Occurrence and infection of Cladosporium, Fusarium, Epicoccum and Aureobasidium in withered rotten grapes during post-harvest dehydration. Antonie Van Leeuwenhoek 2015, 108, 1171-1180. [CrossRef]

63. Overy, D.P.; Frisvad, J.C. Mycotoxin production and postharvest storage rot of ginger (Zingiber officinale) by Penicillium brevicompactum. J. Food Prot. 2005, 68, 607-609. [CrossRef]

64. Zhai, M.-M.; Qi, F.-M.; Li, J.; Jiang, C.-X.; Hou, Y.; Shi, Y.-P.; Di, D.-L.; Zhang, J.-W.; Wu, Q.-X. Isolation of secondary metabolites from the soil-derived fungus Clonostachys rosea YRS-06, a biological control agent, and evaluation of antibacterial activity. J. Agric. Food Chem. 2016, 64, 2298-2306. [CrossRef] [PubMed]

65. Hiol, A.; Jonzo, M.D.; Rugani, N.; Druet, D.; Sarda, L.; Comeau, L.C. Purification and characterization of an extracellular lipase from a thermophilic Rhizopus oryzae strain isolated from palm fruit. Enzym. Microb. Technol. 2000, 26, 421-430. [CrossRef]

66. Wu, G.; Sun, X.; Yu, G.; Wang, W.; Zhu, T.; Gu, Q.; Li, D. Cladosins A-E, hybrid polyketides from a deep-sea-derived fungus, Cladosporium sphaerospermum. J. Nat. Prod. 2014, 77, 270-275. [CrossRef] [PubMed]

67. Oren, A.; Gunde-Cimerman, N. Fungal life in the Dead Sea. In Biology of Marine Fungi; Springer: Berlin, Germany, 2012; pp. 115-132.

68. Dias, A.C.D.S.; Ruiz, N.; Couzinet-Mossion, A.; Bertrand, S.; Duflos, M.; Pouchus, Y.-F.; Barnathan, G.; Nazih, H.; Wielgosz-Collin, G. The marine-derived fungus Clonostachys rosea, source of a rare conjugated 4-Me-6E, 8E-hexadecadienoic acid reducing viability of MCF-7 breast cancer cells and gene expression of lipogenic enzymes. Mar. Drugs 2015, 13, 4934-4948. [CrossRef]

69. Sun, H.-H.; Mao, W.-J.; Jiao, J.-Y.; Xu, J.-C.; Li, H.-Y.; Chen, Y.; Qi, X.-H.; Chen, Y.-L.; Xu, J.; Zhao, C.-Q.; et al. Structural characterization of extracellular polysaccharides produced by the marine fungus Epicoccum nigrum JJY-40 and their antioxidant activities. Mar. Biotechnol. 2011, 13, 1048-1055. [CrossRef]

70. Paz, Z.; Komon-Zelazowska, M.; Druzhinina, I.S.; Aveskamp, M.M.; Shnaiderman, A.; Aluma, Y.; Carmeli, S.; Ilan, M.; Yarden, O. Diversity and potential antifungal properties of fungi associated with a Mediterranean sponge. Fungal Divers. 2010, 42, 17-26. [CrossRef]

71. Wang, F.; Fang, Y.; Zhang, M.; Lin, A.; Zhu, T.; Gu, Q.; Zhu, W. Six new ergosterols from the marine-derived fungus Rhizopus sp. Steroids 2008, 73, 19-26. [CrossRef]

72. Pasqualetti, M.; Barghini, P.; Giovannini, V.; Fenice, M. High production of chitinolytic activity in halophilic conditions by a new marine strain of Clonostachys rosea. Molecules 2019, 24, 1880. [CrossRef]

73. Sun, Y.; Tian, L.; Huang, J.; Ma, H.-Y.; Zheng, Z.; Lv, A.-L.; Yasukawa, K.; Pei, Y.-H. Trichodermatides A-D, novel polyketides from the marine-derived fungus Trichoderma reesei. Org. Lett. 2008, 10, 393-396. [CrossRef]

74. Pruksakorn, P.; Arai, M.; Kotoku, N.; Vilchèze, C.; Baughn, A.D.; Moodley, P.; Jacobs, W.R., Jr.; Kobayashi, M. Trichoderins, novel aminolipopeptides from a marine sponge-derived Trichoderma sp., are active against dormant mycobacteria. Bioorg. Med. Chem. Lett. 2010, 20, 3658-3663. [CrossRef]

75. Garzoli, L.; Poli, A.; Prigione, V.; Gnavi, G.; Varese, G.C. Peacock's tail with a fungal cocktail: First assessment of the mycobiota associated with the brown alga Padina pavonica. Fungal Ecol. 2018, 35, 87-97. [CrossRef]

76. Brown, N.A.; Ries, L.N.A.; Goldman, G.H. How nutritional status signalling coordinates metabolism and lignocellulolytic enzyme secretion. Fungal Genet. Biol. 2014, 72, 48-63. [CrossRef] [PubMed]

77. Cong, B.; Wang, N.; Liu, S.; Liu, F.; Yin, X.; Shen, J. Isolation, characterization and transcriptome analysis of a novel Antarctic Aspergillus sydowii strain MS-19 as a potential lignocellulosic enzyme source. BMC Microbiol. 2017, 17, 1-14. [CrossRef] [PubMed]

78. Oliveira, M.d.S.; Feddern, V.; Kupski, L.; Cipolatti, E.; Badiale-Furlong, E.; de Souza-Soares, L. Physico-chemical characterization of fermented rice bran biomass. CyTA-J. Food 2010, 8, 229-236. 
79. Osono, T.; Fukasawa, Y.; Takeda, H. Roles of diverse fungi in larch needle-litter decomposition. Mycologia 2003, 95, 820-826. [CrossRef]

80. Blaszczyk, L.; Strakowska, J.; Chelkowski, J.; Gabka-Buszek, A.; Kaczmarek, J. Trichoderma species occurring on wood with decay symptoms in mountain forests in Central Europe: Genetic and enzymatic characterization. J. Appl. Genet. 2016, 57, 397-407. [CrossRef]

81. Kim, D.; Orrego, D.; Ximenes, E.A.; Ladisch, M.R. Cellulose conversion of corn pericarp without pretreatment. Bioresour. Technol. 2017, 245, 511-517. [CrossRef]

82. Dien, B.S.; Miller, D.J.; Hector, R.E.; Dixon, R.A.; Chen, F.; McCaslin, M.; Reisen, P.; Sarath, G.; Cotta, M.A. Enhancing alfalfa conversion efficiencies for sugar recovery and ethanol production by altering lignin composition. Bioresour. Technol. 2011, 102, 6479-6486. [CrossRef]

83. Neethu, K.; Rubeena, M.; Sajith, S.; Sreedevi, S.; Priji, P.; Unni, K.; Josh, M.S.; Jisha, V.; Pradeep, S.; Benjamin, S. A novel strain of Trichoderma viride shows complete lignocellulolytic activities. Adv. Biosci. Biotechnol. 2012, 3, 1160. [CrossRef]

84. Van den Brink, J.; Maitan-Alfenas, G.P.; Zou, G.; Wang, C.; Zhou, Z.; Guimarães, V.M.; de Vries, R.P. Synergistic effect of Aspergillus niger and Trichoderma reesei enzyme sets on the saccharification of wheat straw and sugarcane bagasse. Biotechnol. J. 2014, 9, 1329-1338. [CrossRef]

(C) 2019 by the authors. Licensee MDPI, Basel, Switzerland. This article is an open access article distributed under the terms and conditions of the Creative Commons Attribution (CC BY) license (http://creativecommons.org/licenses/by/4.0/). 